\title{
Florida Crop/Pest Management Profile: Herbs (Basil, Cilantro, Dill, Mint, Parsley, Rosemary, Sage, Thyme) ${ }^{1}$
}

Mark A. Mossler

\section{Production Facts}

- Commercial herb production in Florida is conducted by approximately two dozen small or single-person operations. The most prevalent herbs grown are those listed in the title, although small plantings of almost any herb can eventually be located. Herb value and production estimates are not tracked by state or federal agencies.

- Herb acreage is less than 500 acres in total, and is distributed between greenhouse and field grown plants. Cut production is often field based, while live plants (for immediate consumption or replanting) are generally propagated in greenhouses.

\section{Production Regions}

Herbs can be grown throughout the state, but commercial production is concentrated in the southern portion due to the benefit of higher year-round temperatures. There is also some production (field and greenhouse) in the northern part of the state. Cultivation generally occurs throughout the year for greenhouse operations, while field production occurs between late September and May.

\section{Production Practices}

Perennial and biennial herbs (mint, parsley, rosemary, sage, thyme) are often cultivated in the field, while annual herbs (basil, cilantro, dill) are amenable to field or pot culture. Similarly, perennial herbs are often started with cuttings, while annuals are seeded. Spacing ranges between four and twelve inches for most herbs, but seeding rate may be over one million seeds per acre. Most herbs are propagated and harvested over a roughly two-month time frame, with staggered planting dates throughout the season (1).

1. This document is PI-65, one of a series of publications of the Pesticide Information Office, Agronomy Department, Florida Cooperative Extension Service, Institute of Food and Agricultural Sciences, University of Florida. For additional Information, contact the Pesticide Information Office, University of Florida, P. O. Box 110710, Gainesville, Fl 32611-0710, (352) 392-4721. Published November 2005. Please visit the EDIS Web site at http://edis.ifas.ufl.edu.

2. Mark A. Mossler, Doctor of Plant Medicine, Pesticide Information Office, Agronomy Department. Cooperative Extension Service, Institute of Food and Agricultural Sciences, University of Florida, Gainesville, 32611-0710.

The use of chemical names in this publication is solely for the purpose of providing specific information and does not constitute a recommendation. UF/IFAS does not guarantee or warranty the products named, and references to them in this publication does not signify our approval to the exclusion of other products of suitable composition. All chemicals should be used in accordance with directions on the manufacturer's label.

The Institute of Food and Agricultural Sciences (IFAS) is an Equal Opportunity Institution authorized to provide research, educational information and other services only to individuals and institutions that function with non-discrimination with respect to race, creed, color, religion, age, disability, sex, sexual orientation, marital status, national origin, political opinions or affiliations. U.S. Department of Agriculture, Cooperative Extension Service, University of Florida, IFAS, Florida A. \& M. University Cooperative Extension Program, and Boards of County Commissioners Cooperating. Larry Arrington, Dean 


\section{Worker Activities}

Worker activities for the season commence with laying mulch, if this system is employed. The ground is then either directly seeded or transplants are set. Seeded plants are machine drilled into the soil, and thinned (and weeded) after emergence if necessary. Transplants are hand-set by workers. Workers setting transplants (approximately five days for a forty-acre farm) often wear latex gloves. For those operations that do not use herbicides, hand weeding is done once more prior to harvest. A single worker is capable of thinning/hand weeding an acre per day. The only remaining labor includes harvest. Some herbs are picked once, while others have several harvests depending on plant condition.

\section{Pest Management}

Because herbs are vegetative crops, the most important pest groups in Florida production include the early season diseases, weeds, and leaf-feeding insects. Nematodes and viruses are generally not problematic in Florida herb production.

\section{Insect/Mite Management}

\section{Insect/Mite Pests}

The principal arthropod pests on herbs in Florida are lepidoptera larvae (caterpillars). These include cutworms (granulate, black), beet armyworm, and cabbage looper. Although generally not plant damaging, the physical presence of aphids results in lower crop quality. Occasional or minor arthropod pests include thrips, mites, leafminers, and wireworms. Fire ants sometimes disrupt harvest, or become predators of plants for lack of any other food source $(2,3)$.

Cutworms [granulate cutworm, (Feltia subterranea), black cutworm (Agrotis ipsilon)]. Cutworms are stout caterpillars with a dull, greasy appearance. Cutworms cleave seedlings off at or just below the soil line. They may also damage leaves. Black cutworms do most of their feeding at ground level; the larvae feeding on young plants and cutting off leaves, or in later instars, entire plants.

Populations tend to be higher in weedy or wet fields. Granulate cutworm larvae can cut off entire seedling plants, as well as climb and feed on leaves of older plants. This cutworm is not associated with weedy fields as is the black cutworm. First instar larvae remain on the plants, while older larvae climb and feed on plants only during the night. In some areas, natural enemies of cutworms exert control pressure that may approach 80 percent. However, seedlings emerging in fields without this protection can experience substantial stand loss (2).

Beet Armyworm (Spodoptera exigua). Beet armyworm is a slender striped larvae that feeds on leaves. The moth is capable of laying over 600 eggs, in masses of 100, on the underside of plant leaves, which are covered with fuzzy white scales. Larvae emerge from egg masses in three to four days. They feed in groups during the first instar and then disperse on the wind using silken threads. Larvae enter the soil to pupate after one to three weeks of feeding. Adults emerge in 7 to 10 days. Consequently, generations can be spawned monthly (2).

Cabbage Looper (Trichoplusia ni). Another leaf-feeding caterpillar is the cabbage looper, which is green with white stripes along the body. Moths deposit eggs singly or in small groups of up to seven. Females can produce 300 to 600 eggs in their two-week life span. Larvae emerge from eggs in 3 to 4 days and feed on leaves. Larvae develop for two to four weeks, and then spin cocoons on the host plant for pupation. Adults emerge in five to ten days and the entire cycle can take as little as 18 days (2).

Aphids [green peach aphid (Myzus persicae), spirea aphid (Aphis spiraecola), and Hyadaphis coriandri, among others]. Aphids feed by piercing plant tissue with their needle-like mouthparts (stylets), sucking out water and nutrients from the vascular system of the plant. Feeding damage and toxins in the saliva result in thickening, crumpling, and downward curling of leaves. Heavy aphid attack may kill very young plants. Aphids also deposit honeydew on the plant surface, which encourages the growth of sooty mold. A short life cycle and asexual reproduction by live birth allows aphid populations to increase rapidly in Florida (2).

Thrips (Frankliniella spp.). In agricultural areas, field disruptions (disking, mowing, chemical dessication) can drive thrips out of established areas 
and into less hardy vegetation (such as young plants). However, all stages of the plant are vulnerable to feeding damage. Large concentrations of thrips cause leaf damage (malformation). Thrips can complete a generation in 14 to 20 days, but most of the development of the thrips that are feeding on herbs occurs in adjacent weedy areas (4).

Leafminers (Liriomyza sativae and Liriomyza trifolii). The adult fly punctures the upper leaf surface while feeding, and the female inserts eggs into the puncture holes. When each larva (maggot) emerges, it feeds between the upper and lower leaf surfaces, creating a tunnel or mine that winds across the leaf and becomes larger as the maggot grows. When larval development is complete, the maggot cuts through the leaf surface and emerges from its mine, dropping to the soil to pupate. Leafminer populations can increase rapidly in Florida, where the life cycle may be as short as 21 to 28 days (2).

Mites. The twospotted spider mite (Tetranychus urticae) is oval, about $0.5 \mathrm{~mm}$ long, and may be brown or orange-red, but a green, greenish-yellow or an almost translucent color is most common. All mites have needle-like piercing-sucking mouthparts. Spider mites feed by penetrating the plant tissue with their mouthparts and are typically found on the underside of the leaf. Spider mites spin fine strands of webbing on the host plant - hence their name. When twospotted spider mites remove the sap, the mesophyll tissue collapses and a small chlorotic spot forms at each feeding site. Continued feeding causes a stippled-bleached effect on the upper surfaces of leaves and later, the leaves turn yellow, gray or bronze. Complete defoliation may occur if the mites are not controlled (5).

Wireworms (Conoderus spp.). Wireworms, which are larvae of click beetles, are among the most destructive of soil insect pests. Conoderus spp. wireworms, including C. rudis, C. amplicollis (Gulf wireworm), C. falli (southern potato wireworm), and C. verpertinus (tobacco wireworm), are the most common on vegetable crops in Florida. Wireworms cause greatest damage to germinating seeds, and transplants are generally less susceptible. In addition to feeding on seeds before or at germination, wireworms can bore into the tap root and tunnel up the stem or feed on smaller roots of seedlings. They can cause sudden stand reductions by quickly attacking young seedlings, causing wilting, stunting, and death. Click beetles lay their eggs in the soil near plant roots, and upon hatching, the wireworms feed on the nearby roots. Wireworms may spend up to several years in the soil in the larval stage and may be present at a soil depth of 1 to 5 feet (6).

\section{Chemical Control}

Based on a 2004 UF survey, some Florida herb growers applied insecticides on up to 100 percent of their acreage, while others used none at all. There was reported use of azadirachtin, B.t., and sulfur. Other insecticides/miticides registered for all herbs in Florida in 2004 were Beauveria bassiana, petroleum oils, pyrethrins (+/-rotenone), soaps, spinosad, and sucrose octanoate. Methoprene is available for fire ant control. For dill, carbaryl is registered for use as a bait. There are many more insecticides/miticides for mint and parsley since they are often field-grown. For mint, acephate, chlorpyrifos, dicofol, malathion, methomyl, and tebufenozide were registered for use as of 2004. For parsley, acetamiprid, carbaryl (bait and spray), cyromazine, diazinon, emamectin benzoate, imidacloprid, malathion, methomyl, methoxyfenozide, permethrin, pymetrozine, tebufenozide, and thiodicarb were actively registered for use as of 2004.

Azadirachtin (Neemix). Azadirachtin is a natural compound derived from the neem tree (Azadirachta indica) that has insect growth regulator activity. The compound is used to manage caterpillars and aphids. The price of azadirachtin is $\$ 2,119$ per pound of active ingredient and the approximate cost per maximum labeled application $(0.04 \mathrm{lb} \mathrm{ai} / \mathrm{A})$ is $\$ 90.00$ per acre $(7,8)$. Azadirachtin may be applied up to the day of harvest $(\mathrm{PHI}=0$ days), and the restricted entry interval (REI) under the Worker Protection Standard is 4 hours. In 2004, 67 percent of herb growers in Florida applied azadirachtin as needed to up to 100 percent of the crop.

Bacillus thuringiensis. The biopesticide Bacillus thuringiensis (B.t.) is an important management tool for Florida herb growers, who use it every year in the management of problematic caterpillars (armyworms, 
cabbage looper, cutworms). B.t. is a naturally occurring soil bacterium that produces spores and crystalline bodies that act as stomach poisons to insects that consume it. The most common formulations are highly specific for caterpillars and therefore do not harm beneficial organisms. However, it is most effective against smaller larvae. The median price of B.t. is $\$ 10.00$ per pound, which is often the amount used per acre (7). B.t. may be applied up to the day of harvest (PHI=0 days), and the REI is 4 hours. In 2004, 67 percent of herb growers in Florida applied B.t. as needed to up to 100 percent of the crop.

Sulfur. Sulfur is used as a mite management tool. The median price of sulfur is $\$ 0.88$ per pound and the approximate cost per labeled application (10 $\mathrm{lb} / \mathrm{A}$ ) is $\$ 8.80$ per acre (7). The REI for sulfur is 24 hours and there is no PHI. In 2004, 33 percent of herb growers in Florida applied sulfur as needed.

\section{Alternative Chemicals}

Over the past few years, there have been a number of new reduced risk materials registered for use on parsley and mint, but very few for the other six herbs. Spinosad and tebufenozide are good examples of this trend. These materials are generally more selective than those of historic use. These materials are currently being assessed for fit into established IPM systems. Materials such as beet armyworm pheromone are also being evaluated for attract and kill systems.

\section{Cultural Control}

Scouting is the number one cultural practice employed by herb growers, and all growers responded that production areas were scouted regularly and two-thirds recorded such counts. All growers reported using mulches, removing field and perimeter vegetation, and plowing in residue as measures to clean up refugia and reduce local pest populations. They also reported altering planting date and rotating pesticides and crops. Though not reported in the survey, flooding is conducted on as many acres as possible during the summer, which alleviates some of the soil pests, such as cutworms, fire ants, and wireworms.

\section{Biological Control}

There is a measure of natural parasitism for most of the herb pests in Florida. However, most don't control the pests at a rate that precludes economic damage. Some growers are employing biological tools to their management programs and two-thirds of responding growers reported release of some type of beneficial organism.

\section{Disease Management}

\section{Disease Pathogens}

In years of particularly wet weather, diseases that affect early establishment and leaf growth of plants are the most serious disease problems on herbs in Florida. The state's warm, moist climate, as well as the overlapping progression of plantings during the season create conditions ideal for disease development. The most important diseases of herbs are damping off/root rot organisms (Rhizoctonia solani, Fusarium, Pythium), leaf spots caused by fungi (Alternaria, Cercospora, Colletotrichum, and Septoria) or bacteria, and powdery mildew $(3,9,10)$.

Damping Off/root Rot (Rhizoctonia solani, Alternaria spp., Pythium spp.). Whether during emergence (damping off) or early growth (root rot), these soil fungi can colonize root tissue and cause rapid necrosis. Tissue progresses from yellow to brown quickly, as leaf tissue lacking water quickly desiccates. Root systems may also appear reddish with deterioration of secondary roots. When the disease becomes established, it can potentially affect 25 percent of the acreage if not 75 to 80 percent should an outbreak begin early. Mature leaves are generally the first affected by root rot (9).

Leaf Spot (Alternaria radicina, Septoria petroselini, Colletotrichum spp., Cercospora spp.). Almost all of the leaf spot diseases start out as small areas of brown which can become necrotic and fall out (shot hole) or lead to entire leaf necrosis. Alternaria infection may be associated with a chlorotic halo around the spot. Septoria forms small black structures in the lesion (pycnidia) which can distinguish it from the other three fungi $(9,10)$. 
Powdery Mildew (Oidium spp.). Powdery mildew is a ubiquitous fungus that becomes established if weather conditions are conducive (cool and dry with fog or dew). A white coating covers the plant as the fungus grows and plant tissue can become distorted if the fungus is not managed.

Bacterial Diseases (caused by Erwinia carotovora pv. carotovora, Xanthomonas campestris pv. vitians, Pseudomonas secorii). Based on variety, seeding rate, and weather conditions, bacteria may affect roots, leaves, or the entire plant. Lesions are often watersoaked and angular in shape. Under wet conditions, bacterial soft rot (caused by Erwinia carotovora pv. carotovora) can decimate the entire crop, but usually causes less than five percent damage in any given year. A number of bacteria can affect the leaves, either in the field or after the plant has been transported (11).

\section{Chemical Control}

Based on a 2004 UF survey, some Florida herb growers applied fungicides on up to 100 percent of their acreage, while others used none at all. There was reported use of azadirachtin and sulfur. Other fungicides registered for all herbs in Florida in 2004 were Bacillus subtilis, Coniothyrium minitans, fludioxonil (seed treatment only except mint), harpin, mefenoxam (foliar for all herbs and seed treatment for dill), potassium bicarbonate, and Trichoderma harzianum. A blend of peroxyacetic acid and hydrogen peroxide is labeled for post-harvest processing water. As with insecticides, certain fungicides are just labeled for one or several herbs. Azoxystrobin is labeled for use on cilantro; copper hydroxide is labeled for dill, and phosphoric acid is labeled for rosemary. For mint, azoxystrobin, phosphoric acid, and trifloxystrobin were registered for use as of 2004. For parsley, azoxystrobin, fosteyl-Al, phosphoric acid, and pyraclostrobin were actively registered for use as of 2004.

Azadirachtin (Neemix). Azadirachtin is a natural compound derived from the neem tree (Azadirachta indica) that has fungicidal activity. The price of azadirachtin is $\$ 2,119$ per pound of active ingredient and the approximate cost per maximum labeled application (0.04 lb ai/A) is $\$ 90.00$ per acre $(7,8)$. Azadirachtin may be applied up to the day of harvest (PHI $=0$ days), and the REI under the Worker Protection Standard is 4 hours. In 2004, 67 percent of herb growers in Florida applied azadirachtin as needed to up to 100 percent of the crop.

Sulfur. Sulfur is used as a prophylactic fungal management tool, especially for powdery mildew. The median price of sulfur is $\$ 0.88$ per pound and the approximate cost per labeled application $(10 \mathrm{lb} / \mathrm{A})$ is $\$ 8.80$ per acre (7). The REI for sulfur is 24 hours and there is no PHI. In 2004, 33 percent of herb growers in Florida applied sulfur as needed.

\section{Alternative Chemicals}

In addition to strobilurin fungicides such as azoxystrobin, trifloxystrobin, and pyraclostrobin, fludioxonil (for soil-borne pathogens) is a seed treatment that is currently being examined for overall utility in Florida herb production.

\section{Cultural Control}

Scouting is the number one cultural practice employed by herb growers, and all responded that production areas were scouted regularly and two-thirds recorded such counts. A third of growers reported use of weather data for disease management. All growers reported using mulches, removing field and perimeter vegetation, and plowing in residue as measures to reduce disease sources. All growers also reported rotating pesticides and crops. Though not reported in the survey, growers routinely flush out drip irrigation lines to reduce disease sources (3).

\section{Biological Control}

Various organisms have been shown to reduce the impact of pathogens when placed in proximity. Bacillus subtilis, Coniothyrium minitans, and Trichoderma harzianum are three examples of organisms that are labeled for use in herbs. Some growers have begun treating irrigation water with these organisms to distribute them to the plants rhizosphere. 


\section{Weed Management}

\section{Weed Pests}

Since herbs are quick-growing, short season crops, weed competition in the early emergence period for field-grown plants is a critical consideration. For example, one pigweed will reduce the quality of the four lettuce plants (similar to herb plants) around it, and competition within the first five weeks can reduce yield by 50 percent. As stated earlier, thinning and weeding is done from three to four weeks after seeding. Those growers that use no herbicide hand cultivate once again before harvest (at a cost of approximately $\$ 800 /$ acre).

A variety of weeds are problematic for Florida herb producers, including nutsedges (yellow and purple), grasses such as goosegrass, and broadleaf weeds, including pusley and purslane. Amaranths (livid, spiney, or common) are particularly troublesome $(12,13)$.

Amaranth (Amaranthus spp.). Amaranths (pigweeds) are annual broadleaf herbs with erect stems that can grow to six feet tall. Several species of amaranth are present in herb growing areas, including livid amaranth (Amaranthus lividus), smooth pigweed (Amaranthus hybridus), and spiny amaranth (Amaranthus spinosus). Amaranths reproduce solely by seed, producing very small, dark seeds. They prefer open areas with bright sunlight $(14,15)$.

Nutsedge (Cyperus spp.). Yellow nutsedge ( $C$. esculentus) and purple nutsedge (C. rotundus) are problems in Florida herb production. Both of these perennial sedges are found in disturbed habitats throughout Florida and the southeast U.S. Yellow nutsedge may produce some seed but reproduces primarily by rhizomes and tubers. The parental plant develops rhizomes, terminating in bulbs or tubers that produce new plants. Tuber production is favored by low nitrogen levels and high temperatures ( 80 to $91^{\circ} \mathrm{F}$, or 27 to $33^{\circ} \mathrm{C}$ ). The plant is tolerant of high soil moisture but is intolerant of shade. Purple nutsedge is also able to reproduce from tubers under harsh conditions, making it difficult to control. Unlike the rhizomes of yellow nutsedge, purple nutsedge rhizomes growing off the parent plant produce new plants in a series ("tuber-chains"). The plant also reproduces by seed to a limited degree. Although purple nutsedge is also intolerant of shade, it is able to survive a wide range of environmental conditions, growing well in nearly all soil types and over a range of soil moisture, soil $\mathrm{pH}$, and elevation. Purple nutsedge is also able to survive extremely high temperatures (14).

Goosegrass (Eleusine indica). Goosegrass is similar in appearance to crabgrass, but grows more densely and does not root at the nodes. It is also a summer annual, and it prefers sunny, moist conditions. Reproducing by seed, it flowers from July to October $(14,15)$.

Florida Pusley (Richardia scabra). Florida pusley is a loosely branched annual that may grow erect or prostrate. Its hairy stems and oppositely arranged leaves are often rough in texture, particularly along the main veins. The plant is often mixed with Brazilian pusley ( $R$. brasiliensis). Florida pusley reproduces by seed and blooms in any month in the absence of frost (16).

Purslane (Portulaca oleracea). Purslane is a broadleaf summer annual with a single taproot from which arise multiple branched, purplish-red stems that often form large mats. Clusters of small leaves are found at the end of its branches. The plant reproduces by seed, flowering from August to October. Being resistant to drought, it is difficult to control. However, it is susceptible to frost injury $(14,15,17)$.

\section{Chemical Control}

In 2004, Florida herb growers did not report the use of any herbicides for production. Herbicides registered for all herbs in Florida in 2004 were glyphosate and pelargonic acid. As with other pesticides, certain herbicides are just labeled for one or several herbs. Prometryn is registered via Special Local Need authorization for use in both parsley and dill. Sethoxydim is registered for cilantro, and trifluralin is registered for rosemary. For mint, bromoxynil (dormant use), clethodim, fenoxaprop, imazapic, napropamide, paraquat (dormant use), quizalofop, sethoxydim, and trifluralin were registered for use as of 2004. Additionally, linuron, 
bensulide, and sethoxydim were actively registered for use in parsley as of 2004.

\section{Alternative Chemicals}

With minimal commercial herb production, Florida makes few requests for IR-4 assistance in this area. Consequently, there are few new chemical herbicide alternatives.

\section{Cultural Control}

Although flooding is done for disease management reasons, this practice also aids in weed control to some extent. A portion of weed seed is inactivated by prolonged flooding. Even though herbs are short-season crops, there is hand weeding. There is manual removal at thinning and blocking, and again a few weeks later if the herbicide performs poorly or one is not used. Growers also reported using mulches as another way to reduce weed growth.

\section{Nematode Management}

Nematodes are microscopic roundworms living in the soil which feed on plant roots and damage the tissue. Since some of the commercial herb production is associated with muck soils, which have historically few nematode problems due to flooding, little management is practiced. A five year rotation is suggested for most field-grown plants and all growers responded that rotation was practiced. Most soil sterilants are too expensive for herb growers to use (3). For those growers attempting to grow herbs on soils more conducive to nematode damage, dichloropropene (mint only) and metam sodium are labeled for this use. Fermentation products of Myrothecium verrucaria are also registered as a nematicidal treatment in herbs.

\section{Slug/Snail Management}

Snails and slugs are sometimes problematic in Florida herb production. Although none of the growers reported the use of any pesticide to control these animals, metaldehyde is registered for use on dill, parsley, mint, and sage as of 2004.

\section{Key Contacts}

- Michael Aerts is the assistant director of the Environmental and Pest Management Division of Florida Fruit and Vegetable Association. He facilitates communication between commodity and regulatory agencies. Mr. Aerts can be reached at: FFVA, 800 Trafalgar Ct. Suite Maitland, FL 32794-8153, (321) 214-5200, maerts@ffva.com.

- Mark Mossler is a Doctor of Plant Medicine in the Pesticide Information Office at the University Floridas Institute of Food and Agricultural Sciences. He is responsible for providing information to the public and governmental agencies. Dr. Mossler can be reached at PIO, Box 110710, Gainesville, FL 32611, (352) 392-4721, mamossler@ifas.ufl.edu.

\section{References}

1. Hochmuth, G.J., Maynard, G.J., Vavrina, C.S., Stall, W.M., Kucharek, T.A., Webb, S.E. (2004). Parsley Production in Florida. Horticultural Sciences Department HS731. Florida Cooperative Extension Service, Institute of Food and Agricultural Sciences, University of Florida.

2. Webb, S.E. (2004). Insect Management for Celery and Parsley. Entomology \& Nematology Department document ENY-463. Florida Cooperative Extension Service, Institute of Food and Agricultural Sciences, University of Florida.

3. Personal communication, Dr. Mary Lamberts, Miami-Dade Extension Service, 2004.

4. Nuessly, G.N. and Webb, S.E. (2003). Insect Management for Leafy Vegetables (Lettuce, Endive, and Escarole). Entomology \& Nematology Department document ENY-475. Florida Cooperative Extension Service, Institute of Food and Agricultural Sciences, University of Florida.

5. Fasulo, T.R., and Denmark, H.A. (2004). Twospotted spider mite. UF/IFAS Features Creatures. EENY-150. 
6. Johnson, F.A. and Stansly, P.A. (1999). Insects That Affect Vegetable Crops. Entomology and Nematology Department ENY 450. Florida Cooperative Extension Service, Institute of Food and Agricultural Sciences, University of Florida.

7. Personal communication with Helena

Chemicals, Alachua, FL, 2004.

8. Certis labels, Columbia, MD.

9. Raid. R. and Roberts, P. (2005). 2005 Florida Plant Disease Management Guide: Parsley. Department of Plant Pathology document PDMG-V3-43. Florida Cooperative Extension Service, Institute of Food and Agricultural Sciences, University of Florida.

10. Roberts, P. (2005). 2005 Florida Plant Disease Management Guide: Sweet Basil. Department of Plant Pathology document PP113. Florida Cooperative Extension Service, Institute of Food and Agricultural Sciences, University of Florida.

11. Pernezny, K. and Raid, R. (2005). 2005

Florida Plant Disease Management Guide: Lettuce and Endive. Department of Plant Pathology document PDMG-V3-40. Florida Cooperative Extension Service, Institute of Food and Agricultural Sciences, University of Florida.

12. Stall, W.S. (2003). Weed Control in Parsley. Horticultural Sciences Department document HS952. Florida Cooperative Extension Service, University of Florida, Institute of Food and Agricultural Sciences.

13. Stall, W.S. and Dusky, J.A. (2003). Weed Control in Leafy Vegetables (Lettuce, Endive, Escarole, and Spinach). Horticultural Sciences Department document HS203. Florida Cooperative Extension Service, University of Florida, Institute of Food and Agricultural Sciences.

14. Miller, J.F., Worsham, A.D., McCormick, L.L., Davis, D.E., Cofer, R. and Smith, J.A. (1975). Weeds of the Southern United States. Florida Cooperative Extension Service, Institute of Food and Agricultural Sciences, University of Florida. Gainesville, Florida.

15. Lorenzi, H.J. and Jeffery, L.S. (1987). Weeds of the United States and Their Control. Van Nostrand Reinhold Company, New York.

16. Stall, W.M. (2003). Weed Control in Cucurbit Crops (Muskmelon, Cucumber, Squash, and Watermelon). Horticultural Sciences Department document HS190. Florida Cooperative Extension Service, University of Florida, Institute of Food and Agricultural Sciences.

17. Stephens, J.M. (1994). Purslane - Portulaca oleracea L. Horticultural Sciences Department Fact Sheet HS-651, Florida Cooperative Extension Service, Institute of Food and Agricultural Sciences, University of Florida. 